\title{
Correlation between survivin mRNA expression and lymph node metastasis in gastric cancer
}

\author{
Kazuhito Miyachi, Kinro Sasaki, Shinichi Onodera, Taizo Taguchi, Masao Nagamachi, Hiromi Kaneko, \\ and Masakatsu Sunagawa
}

First Department of Surgery, Dokkyo University School of Medicine, 880 Kitakobayashi, Mibu, Tochigi 321-0293, Japan

\begin{abstract}
Background. Correlations between the malignant potential and prognosis of cancer and abnormal control mechanisms of apoptosis have been discovered in a variety of cancers. Survivin is a member of the inhibiting apoptosis protein family that is abundant in embryonic and carcinoma tissues. We measured the expression of survivin $\mathrm{mRNA}$ in gastric cancer to determine whether levels of survivin mRNA expression could serve as an index of malignancy.

Methods. Expression of survivin mRNA was measured in samples of both gastric cancer and noncancerous tissue from 107 patients. Survivin mRNA was detected by the real-time polymerase chain reaction (PCR) method, and then the relationship between the survivin mRNA level and histological diagnosis was analyzed.

Results. Expression of survivin mRNA was observed in 105 of 107 cancerous tissues and in 101 of 107 noncancerous tissues. The Mean value of survivin mRNA expression in cancerous tissue was $5.18 \pm 1.30$, significantly higher $(P<0.01)$ than that in noncancerous tissue, at $4.21 \pm 1.48$. No significant differences were found in the values of survivin mRNA expression according to histological classification or according to increasing depth of tumor invasion. However, survivin mRNA expression was significantly higher $(P<0.01)$ in patients displaying lymph node metastasis $(5.48 \pm 1.01)$ than in patients without the metastasis $(4.70 \pm 1.55)$.

Conclusion. These results indicate that increased survivin mRNA expression begins in the early stages of gastric carcinogenesis. Moreover, the level of survivin mRNA expression may indicate the potential for lymph node metastasis in patients with gastric cancer.
\end{abstract}

Key words Survivin mRNA · Gastric cancer · Noncancerous gastric tissue $\cdot$ Lymph-node metastasis $\cdot$ Real-time PCR

Offprint requests to: $\mathrm{K}$. Miyachi

Received: December 20, 2002 / Accepted: July 28, 2003

\section{Introduction}

Apoptosis plays an important role in the developmental morphogenesis [1] and differentiation of fetal human organs and in homeostatic maintenance in mature human organs by removing senescent or unneeded cells [2]. When the functional control of apoptosis is disturbed, homeostatic maintenance becomes impossible, and numerous disorders can result [3]. In the case of such dysfunction, cells that would otherwise be removed by apoptosis remain and multiply, creating the potential for increasing numbers of cells carrying abnormal genes. This suggests an important connection between the abnormal functional control of apoptosis and the neoplastic transformation of cells into a carcinoma. Furthermore, cancerous cells may continue growing by inhibiting the apoptosis induced by natural defense products such as Fas and tumor necrosis factor (TNF), and the apoptosis induced by cancer therapies such as anticancer drugs and radiation [4-7]. The roles of various genes and proteins in the induction and control of apoptosis have been investigated. Research has demonstrated that damaged DNA is put together with the cancer suppressor gene $p 53$ and that the activated p53 protein sends apoptosis-inducing signals $[8,9]$. In another pathway, mitochondrial membranes are broken down by an apoptosis-inducing factor, and apoptosisinducing signals (i.e., cytochrome $\mathrm{C}$ ) are subsequently discharged from the mitochondria [9]. In this pathway, bcl-2 acts to stabilize the mitochondrial membrane and thus suppresses apoptosis [10]. Therefore, abnormalities of $p 53$ and high levels of $b c l-2$ expression may indicate dysfunctional control of apoptosis and could, therefore, represent possible indices of malignancy. In addition, malignant potential is reportedly higher for gastric cancer patients displaying these changes in $p 53$ and $b c l-2$ $[11,12]$. Recently, survivin was discovered as a member of the inhibiting apoptosis protein (IAP) family [13]. Increased levels of survivin expression have been re- 
ported in carcinomas [13-15]. The worst prognoses have been noted in patients with hematopoietic disease, neuroblastoma, renal tumor, and mammary cancer in whom survivin expression was high [16-19]. Previous studies have also reported a relationship between survivin expression and both the prognosis and the cell proliferation kinetics in patients with gastric cancer $[20,21]$. In previous clinical studies of cancer, survivin expression has been examined by immunostaining and immunoblotting for the protein; little investigation has been performed at the genetic level [15,22-24]. In the present study, we examined the expression of survivin mRNA in gastric cancer by the real-time polymerase chain reaction (PCR) amplification method, and then compared semiquantitative values for survivin mRNA expression with histopathological findings from the cancers, to determine whether the level of survivin mRNA expression could serve as an index of malignancy.

\section{Subjects, materials, and methods}

\section{Gastric tissue}

Samples were obtained from 107 stomachs surgically resected at the First Department of Surgery, Dokkyo University School of Medicine, between September 1999 and August 2002. Tumors were located in the upper third of the stomach in 23 patients, in the middle third in 47, and in the lower third of the stomach in 37. Total gastrectomy was performed in 21 patients, proximal partial gastrectomy in 2, and distal partial gastrectomy in 84 . We obtained 107 cancerous tissue samples, and 107 noncancerous tissue samples that were found more than $3 \mathrm{~cm}$ away from cancerous tissue. Informed consent was obtained from all 107 subjects in this study. For each tissue sample, one-half was used for histological diagnosis under standard hematoxylin-eosin staining and the other for survivin mRNA measurements.

Histological diagnosis was performed according to the second English edition of the Japanese classification of gastric carcinoma [25]. Of the 107 cancerous samples, 52 were differentiated (pap, tub1, and tub2) adenocarcinomas and 55 were undifferentiated (sig, por, and muc) adenocarcinomas. When samples were classified by depth of tumor invasion, 28 were T1, 33 were T2, 31 were T3, and 15 were T4. When samples were classified on the basis of lymph node metastasis, 41 were N0, 27 were N1, 19 were N2, and 20 were N3. In addition, hepatic metastasis was recognized in 6 patients and peritoneal metastasis was recognized in 22 patients.

\section{Real-time PCR}

Survivin mRNA was detected using a real-time PCR amplification method [26-29]. Total RNA was ex- tracted from each 5-mg tissue sample by acid guanidine thiocyanate-phenol-chloroform extraction, using RNAzolB (Sawady, Tokyo, Japan) and collected by ethanol precipitation [30]. Complementary DNA was synthesized using a survivin 466-485 primer (5'-AGA GGC CTC AAT CCA TGG CA-3') and glyceraldehyde-3-phosphate dehydrogenase (G3PDH), with an exon 8 primer $\left(5^{\prime}\right.$-CCT GAT GTC ATC ATA TTT GGC AGG-3') as an internal control. The amplification reaction mixture was prepared using TaqMan Universal Master mix (Perkin-Elmer Applied Biosystems, Foster City, CA, USA). The primer set for amplifying the survivin mRNA was designed according to data from Gene Bank NM001168, using primers for exon 1 (survivin [SVN]-forward [F]): 5'-AGA ACT GGC CCT TCT TGG AGG-3' and exons 2-3 (SVN-reverse [R]): 5'-CTT TTT ATG TTC CTC TAT GGG GTC-3'. The probe for these exons (SVN-probe [P]): 5'-AGC GGA TGG CCG AGG CTG GCT TC-3') was designed to target an internal region between the SVN-F and SVN$\mathrm{R}$ primers. This primer set did not detect survivin-beta mRNA. The primer set for amplification of the G3PDH mRNA was designed according to data from Gene Bank M33197, using primers for exon 7: 5'-TGC ACC ACC AAC TGC TTA GCA CCC-3' and exon 8: 5'CTT GAT GTC ATC ATA TTT GGC AGG-3'. The probe for G3PDH-P was based on exons 7-8: 5'-TGA CCA CAG TCC ATG CCG TCA CTG C-3'. Each real-time amplification reaction proceeded for 50 cycles $\left(95^{\circ} \mathrm{C}\right.$ for $30 \mathrm{~s}, 60^{\circ} \mathrm{C}$ for $40 \mathrm{~s}$, and $72^{\circ} \mathrm{C}$ for $30 \mathrm{~s}$ ) and was tracked by the ABI Prism 7700 sequence detection system (Perkin-Elmer Applied Biosystems) (Fig. 1).

The following examination was performed in order to confirm whether the amplified product was indeed survivin. The mRNA amplification products were purified using a commercial kit (Roche Diagnostics, Mannheim, Germany) and directly sequenced using another commercial kit (Thermo Sequence Cy5 Dye Terminator kit; Amersham Pharmacia Biotech, Uppsala, Sweden) and an automated laser fluorescence DNA sequencer (ALF Express; Amersham Pharmacia Biotech). The resulting sequences were compared with target mRNA sequences.

The semiquantitative value for survivin mRNA expression was determined as the index value of the logarithm of the light emission value of the sample RNA relative to that of standard RNA (for example, a value of " 5.84 " represents $10^{5.84}$ copies per $\mu \mathrm{g}$ total mRNA). Values for results are given as means \pm SD unless otherwise stated.

\section{Statistical analysis}

Semiquantitative values for survivin mRNA expression in cancerous and noncancerous samples were examined 


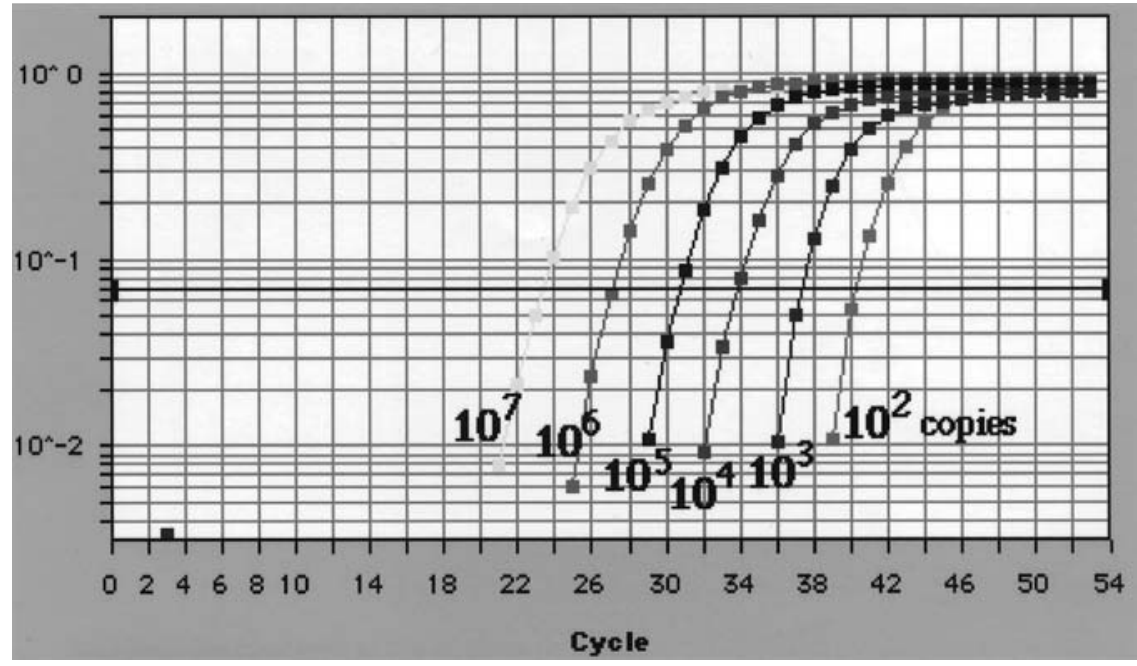

Fig. 1. Real-time polynerase chain reaction (PCR) for serial dilutions of a survivin cDNA clone was performed using a one-step method, with a FAM-labeled reporter primer, a TAMRA-labeled quencher primer, and TaqMan Universal Master Mix (PE Applied Biosystems). Reaction mixtures were incubated, and this was followed by 50 cycles of $95^{\circ} \mathrm{C}$ for $30 \mathrm{~s}, 60^{\circ} \mathrm{C}$ for $40 \mathrm{~s}$, and $72^{\circ} \mathrm{C}$ for $30 \mathrm{~s}$ by using the Wilcoxon signed rank test. The semiquantitative values for survivin mRNA expression were compared with histological classification, depth of tumor, and lymph node metastasis, by using the MannWhitney $U$-test. High and low levels of survivin mRNA expression were compared with histological classification, depth of tumor, and lymph node metastasis, using the $\chi^{2}$ test.

$P$ values of less than 0.05 were judged to be statistically significant.

\section{Results}

\section{Expression of survivin $m R N A$}

Survivin mRNA was detected in 105 of 107 (98.1\%) cancerous tissues and in 101 of 107 (94.4\%) noncancerous tissues: The mean value of survivin mRNA expression in cancerous tissues was $5.18 \pm 1.30$, significantly higher $(P<0.01)$ than that in noncancerous tissues, at $4.21 \pm 1.48$ (Figs 2, 3). As survivin mRNA was expressed in most cancerous tissue samples, we divided these samples into these with relatively high and low levels of expression, with the cutoff value being 5.56, the median value of survivin mRNA expression in cancerous tissues.

\section{Relationship between expression of survivin $m R N A$ and histological type}

The mean value for survivin mRNA expression in differentiated gastric cancers was $5.17 \pm 1.40$, not significantly different from that in undifferentiated gastric cancers, at $5.20 \pm 1.20$ (Table 1). Of the 52 differentiated cancers, 27 (51.9\%) showed high survivin mRNA expression. Of the 55 undifferentiated cancers, 27
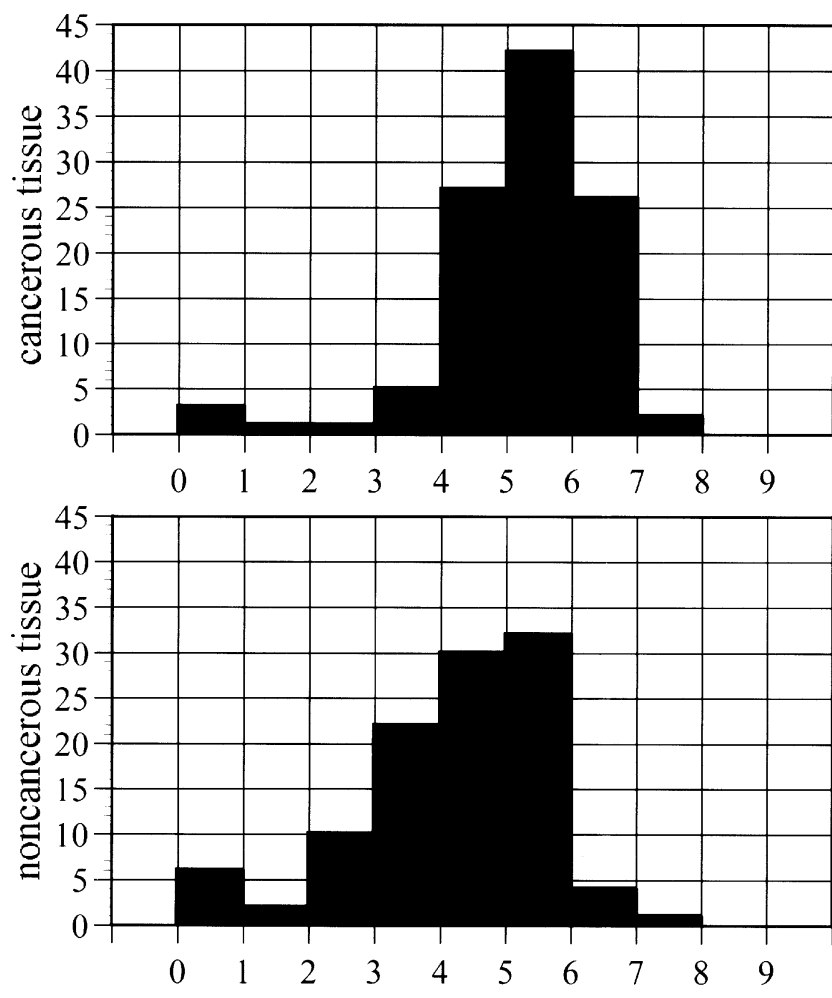

log copies per microgram total mRNA

Fig. 2. Distribution of semiquantitative values of survivin mRNA expression in gastric cancerous and noncancerous tissues. Expression of survivin mRNA was observed in 105 of $107(98.1 \%)$ cancerous tissues and in 101 of $107(94.4 \%)$ noncancerous tissues

(49.1\%) showed high survivin mRNA expression. No apparent relationship was found between high survivin mRNA expression and the histological type of gastric cancer; increased survivin expression was thus recog- 


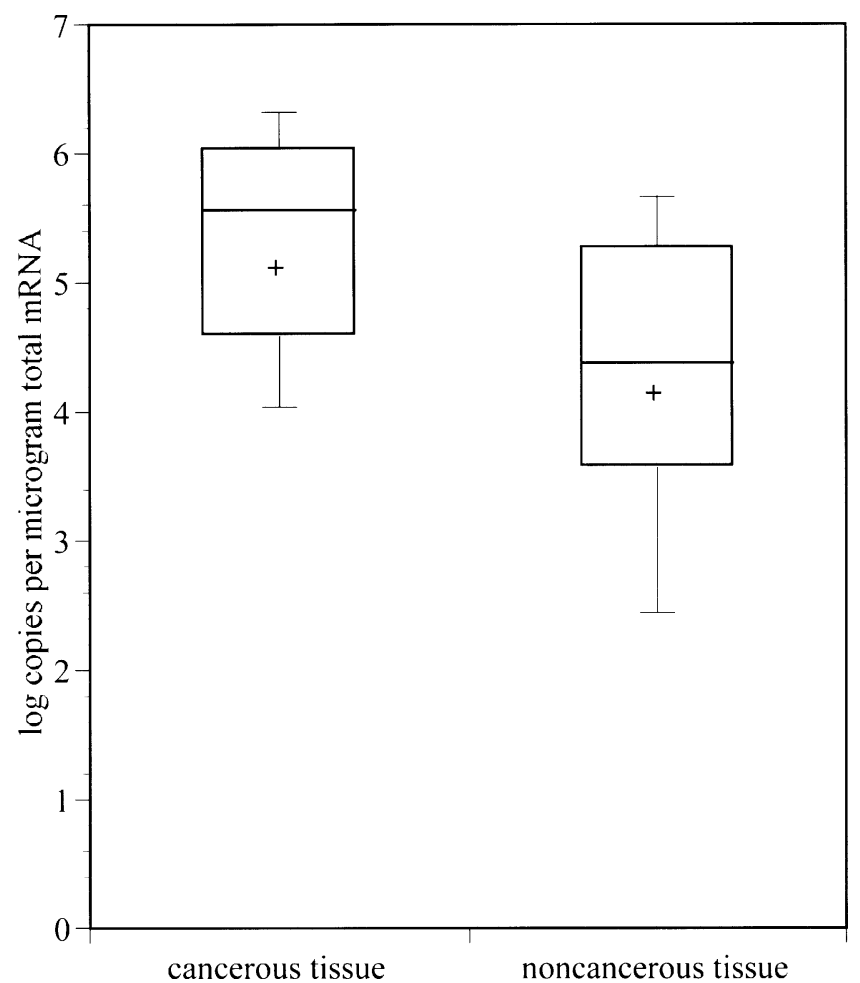

Fig. 3. Proportion of semiquantitative values of survivin mRNA expression in gastric cancerous and noncancerous tissues. The median values for survivin mRNA expression were 5.56 in cancerous tissue and 4.38 in noncancerous tissue. The interquartile ranges were 4.60 to 6.03 in cancerous tissue and 3.58 to 5.27 in noncancerous tissue. The mean value for survivin mRNA expression in cancerous tissue was $5.18 \pm$ 1.30, significantly higher than that in noncancerous tissues at $4.21 \pm 1.48(P<0.01$; Mann-Whitney U-test $)$ nized to be associated with carcinogenesis regardless of the histological type of the gastric cancer.

\section{Relationship between expression of survivin $m R N A$ and depth of primary tumor}

With increasing depth of tumor invasion, the values for survivin mRNA expression were $5.04 \pm 1.30$ in T1, 5.01 \pm 1.80 in $\mathrm{T} 2,5.39 \pm 0.82$ in $\mathrm{T} 3$, and $5.42 \pm 0.61$ in $\mathrm{T} 4$ (Table 2). High survivin mRNA expression was shown by $50.0 \%(14 / 28)$ in $\mathrm{T} 1,48.5 \%(16 / 33)$ in $\mathrm{T} 2,51.6 \%(16 /$ $31)$ in $\mathrm{T} 3$, and $53.3 \%(8 / 15)$ in T4. No significant differences were found in the values for survivin mRNA expression according to increasing depth of tumor invasion. This indicates that the increased expression of survivin mRNA begins in the early phase of the gastric carcinogenesis rather than increasing with the progression of the tumor.

\section{Relationship between expression of survivin $m R N A$ and lymph node metastasis}

The value for survivin mRNA expression in the 66 patients with lymph node metastasis was $5.48 \pm 1.01$, significantly higher $(P=0.002)$ than that in the 41 patients without lymph node metastasis, at $4.70 \pm 1.55$ (Table 1). Of the 66 patients with lymph node metastasis, $38(57.6 \%)$ showed high survivin mRNA expression, a significantly higher proportion $(P<0.05)$ than the 16 of $41(39.0 \%)$ patients without lymph node metastasis (Table 1).

Table 1. Correlation of survivin mRNA expression and histopathological findings in gastric cancer

\begin{tabular}{|c|c|c|c|c|c|c|c|}
\hline & & \multicolumn{2}{|c|}{$\begin{array}{c}\text { Expression } \\
\text { of survivin } \\
\text { mRNA }\end{array}$} & \multirow[b]{2}{*}{$P$ value $^{\mathrm{a}}$} & \multirow{2}{*}{$\begin{array}{c}\text { Positive } \\
\text { ratio of } \\
\text { high group }\end{array}$} & \multirow{2}{*}{$\begin{array}{l}\text { Expression of } \\
\text { survvin mRNA } \\
(\text { mean } \pm \mathrm{SD})^{\mathrm{c}}\end{array}$} & \multirow[b]{2}{*}{$P$ value ${ }^{\mathrm{b}}$} \\
\hline & & High & Low & & & & \\
\hline \multirow{2}{*}{$\begin{array}{l}\text { Histological } \\
\text { classification }\end{array}$} & Differentiated type & 27 & 25 & \multirow[t]{2}{*}{0.919} & $51.9 \%$ & $5.17 \pm 1.40$ & \multirow[t]{2}{*}{0.813} \\
\hline & Undifferentiated type & 27 & 28 & & $49.1 \%$ & $5.20 \pm 1.20$ & \\
\hline \multirow{2}{*}{$\begin{array}{l}\text { Lymph node } \\
\text { metastasis }\end{array}$} & Existence & 38 & 28 & \multirow[t]{2}{*}{0.095} & $57.6 \%$ & $5.48 \pm 1.01$ & \multirow[t]{2}{*}{0.002} \\
\hline & Absent & 16 & 25 & & $39.0 \%$ & $4.70 \pm 1.55$ & \\
\hline \multirow{2}{*}{$\begin{array}{l}\text { Lymphatic } \\
\text { invasion }\end{array}$} & Existence & 45 & 37 & \multirow[t]{2}{*}{0.154} & $54.9 \%$ & $5.38 \pm 1.06$ & \multirow[t]{2}{*}{0.016} \\
\hline & Absent & 9 & 16 & & $36.0 \%$ & $4.52 \pm 1.75$ & \\
\hline \multirow[t]{2}{*}{ Liver metastasis } & Existence & 4 & 2 & \multirow[t]{2}{*}{0.689} & $66.7 \%$ & $5.77 \pm 0.54$ & \multirow[t]{2}{*}{0.147} \\
\hline & Absent & 50 & 51 & & $49.5 \%$ & $5.15 \pm 1.32$ & \\
\hline \multirow[t]{2}{*}{ Venous invasion } & Existence & 36 & 36 & \multirow[t]{2}{*}{$>0.999$} & $50.0 \%$ & $5.21 \pm 1.30$ & \multirow[t]{2}{*}{0.550} \\
\hline & Absent & 18 & 17 & & $51.4 \%$ & $5.13 \pm 1.31$ & \\
\hline \multirow{2}{*}{$\begin{array}{l}\text { Peritoneal } \\
\text { metastasis }\end{array}$} & Existence & 8 & 14 & \multirow[t]{2}{*}{0.212} & $36.4 \%$ & $5.03 \pm 1.36$ & \multirow[t]{2}{*}{0.598} \\
\hline & Absent & 46 & 39 & & $54.1 \%$ & $5.22 \pm 1.29$ & \\
\hline
\end{tabular}

a $\chi^{2}$ test with Yates' correction

${ }^{b}$ Mann-Whitney $U$-test

cSurvivin mRNA expression as log copies/ $\mu$ g total mRNA 
Table 2. Relationship between expression of survivin mRNA and depth of primary tumor invasion

\begin{tabular}{|c|c|c|c|c|c|c|}
\hline \multirow[b]{2}{*}{ Depth of invasion } & \multicolumn{2}{|c|}{$\begin{array}{c}\text { Expression of } \\
\text { survivin mRNA }\end{array}$} & \multirow[b]{2}{*}{$P$ value ${ }^{a}$} & \multirow{2}{*}{$\begin{array}{l}\text { Positive ratio of } \\
\text { high group }\end{array}$} & \multirow{2}{*}{$\begin{array}{l}\text { Expression of survivin mRNA } \\
\quad(\text { mean } \pm \mathrm{SD})^{\mathrm{c}}\end{array}$} & \multirow[b]{2}{*}{$P$ value ${ }^{\mathrm{b}}$} \\
\hline & High & Low & & & & \\
\hline $\mathrm{T} 1$ & 14 & 14 & & $50.0 \%$ & $5.04 \pm 1.30$ & \\
\hline $\mathrm{T} 2$ & 16 & 17 & $>0.999$ & $48.5 \%$ & $5.01 \pm 1.80$ & 0.659 \\
\hline $\mathrm{T} 3$ & 16 & 15 & $>0.999$ & $51.6 \%$ & $5.39 \pm 0.82$ & 0.210 \\
\hline $\mathrm{T} 4$ & 8 & 7 & $>0.999$ & $53.3 \%$ & $5.42 \pm 0.61$ & 0.575 \\
\hline
\end{tabular}

${ }^{a} \chi^{2}$ test with Yates' correction; T0 vs T2, T3, T4

${ }^{\mathrm{b}}$ Mann-Whitney $U$-test; T0 vs T2, T3, T4

c Survivin mRNA expression as log copies/ $\mu \mathrm{g}$ total mRNA

Table 3. Correlation of expression of survivin mRNA and lymph node metastasis

\begin{tabular}{|c|c|c|c|c|c|c|}
\hline \multirow{2}{*}{$\begin{array}{l}\text { Lymph node } \\
\text { metastasis }\end{array}$} & \multicolumn{2}{|c|}{$\begin{array}{l}\text { Expression of } \\
\text { survivin mRNA }\end{array}$} & \multirow[b]{2}{*}{$P$ value $^{\mathrm{a}}$} & \multirow{2}{*}{$\begin{array}{l}\text { Positive ratio of } \\
\text { high group }\end{array}$} & \multirow{2}{*}{$\begin{array}{l}\text { Expression of survivin } \\
\text { mRNA }(\text { mean } \pm \text { SD) }\end{array}$} & \multirow[b]{2}{*}{$P$ value } \\
\hline & High & Low & & & & \\
\hline N0 & 16 & 25 & & $39.0 \%$ & $4.70 \pm 1.55$ & \\
\hline N1 & 18 & 9 & 0.047 & $66.7 \%$ & $5.53 \pm 1.73$ & 0.005 \\
\hline $\mathrm{N} 2$ & 8 & 11 & $>0.999$ & $42.1 \%$ & $5.41 \pm 0.79$ & 0.058 \\
\hline N3 & 12 & 8 & 0.203 & $60.0 \%$ & $5.49 \pm 0.79$ & 0.029 \\
\hline
\end{tabular}

${ }^{\text {a }} \chi^{2}$ test with Yates' correction; N0 vs N1, N2, N3

${ }^{\mathrm{b}}$ Mann-Whitney $U$-test; N0 vs N1, N2, N3

${ }^{\mathrm{c}}$ Survivin mRNA expression as log copies/ $\mu \mathrm{g}$ total mRNA

Table 4. Relationship between expression of survivin mRNA and lymph node metastasis according to depth of tumor invasion

\begin{tabular}{|c|c|c|c|c|c|}
\hline \multirow[b]{2}{*}{ Depth of tumor } & \multirow{2}{*}{$\begin{array}{c}\text { Expression of } \\
\text { survivin mRNA }\end{array}$} & \multicolumn{2}{|c|}{$\begin{array}{l}\text { Lymph node } \\
\text { metastasis }\end{array}$} & \multirow{2}{*}{$\begin{array}{l}\text { Positive ratio of lymph } \\
\text { node metastasis }\end{array}$} & \multirow[b]{2}{*}{$P$ value $^{\mathrm{a}}$} \\
\hline & & N0 & N1-3 & & \\
\hline \multirow[t]{2}{*}{$\mathrm{T} 1$} & High & 11 & 3 & $21.4 \%$ & 0.581 \\
\hline & Low & 13 & 1 & $7.1 \%$ & \\
\hline \multirow[t]{2}{*}{$\mathrm{T} 2$} & High & 3 & 13 & $81.3 \%$ & 0.091 \\
\hline & Low & 9 & 8 & $53.3 \%$ & \\
\hline \multirow[t]{2}{*}{ T3 } & High & 1 & 15 & $93.8 \%$ & 0.534 \\
\hline & Low & 3 & 12 & $80.0 \%$ & \\
\hline \multirow[t]{2}{*}{$\mathrm{T} 4$} & High & 1 & 7 & $87.5 \%$ & $>0.999$ \\
\hline & Low & 0 & 7 & $100.0 \%$ & \\
\hline \multirow[t]{2}{*}{$\mathrm{T} 2-4$} & High & 5 & 35 & $87.5 \%$ & 0.088 \\
\hline & Low & 12 & 27 & $69.2 \%$ & \\
\hline
\end{tabular}

${ }^{\text {a }} \chi^{2}$ test with Yates' correction

Of the 54 patients demonstrating high survivin mRNA expression, those with lymph node metastasis accounted for $38(70.3 \%)$ and those without lymph node metastasis accounted for the remaining 16 (29.7\%). In the other 53 patients, with low survivin mRNA expression, 28 had lymph node metastasis $(52.8 \%)$ and 25 had no lymph node metastasis (47.2\%). With increasing degree of lymph node metastasis, values for survivin mRNA expression were $5.53 \pm 1.31$ in $\mathrm{N} 1,5.41 \pm 0.79$ in N2, and $5.49 \pm 0.79$ in N3 (Table 3). High survivin mRNA expression was seen in $66.7 \%$ (18/ $27)$ in $\mathrm{N} 1,42.1 \%(8 / 19)$ in $\mathrm{N} 2$, and $60.0 \%(12 / 20)$ in $\mathrm{N} 3$.
No apparent relationship was found between high survivin mRNA expression and degree of lymph node metastasis in the patients with gastric cancer.

Relationship between expression of survivin $m R N A$ and lymph node metastasis according to the depth of tumor invasion

At each invasion depth from $\mathrm{T} 1$ to $\mathrm{T} 4$, lymph node metastasis was more prevalent in patients who also showed high survivin mRNA expression (Table 4). However, no significant relationship was found between 
the level of survivin mRNA expression and lymph node metastasis at any invasion depth, suggesting that high survivin mRNA expression is related only to lymph node metastasis, independent of tumor progression.

\section{Relationship between expression of survivin $m R N A$ and lymphatic invasion}

The mean value for survivin mRNA expression in patients with lymphatic invasion was $5.38 \pm 1.06$, significantly higher $(P=0.016)$ that that in patients without lymphatic invasion, at $4.52 \pm 1.75$ (Table 1 ). Of the 54 patients displaying high survivin mRNA expression, 45 $(83.3 \%)$ revealed lymphatic invasion, not significantly different from the $37 / 53(69.8 \%)$ of patients demonstrating low survivin mRNA expression and lymphatic invasion.

\section{Relationship between expression of survivin $m R N A$ and liver metastasis}

The mean value for survivin mRNA expression in the six patients with liver metastasis was $5.77 \pm 0.54$, not significantly higher than that in patients without liver metastasis, at $5.15 \pm 1.32$ (Table 1). High survivin mRNA expression was seen in four of the six patients with liver metastasis $(66.7 \%)$ and in 50 of the 101 patients without liver metastasis (49.5\%); again, not a significant difference.

\section{Relationship between expression of survivin $m R N A$ and venous invasion}

The mean value for survivin mRNA expression in the patients with venous invasion was $5.21 \pm 1.30$, not significantly higher than that in the patients without venous invasion, at $5.13 \pm 1.31$ (Table 1). Of the patients displaying high survivin mRNA expression, $66.7 \%(36 / 54)$ also revealed venous invasion, not a significant difference from the $67.9 \%(36 / 53)$ of the patients who showed both low survivin mRNA expression and venous invasion.

\section{Relationship between expression of survivin $m R N A$ and peritoneal metastasis}

The mean value for survivin mRNA expression in the 22 patients with peritoneal metastasis was $5.03 \pm 1.36$, not significantly different from that in the patients without peritoneal metastasis, at 5.22 \pm 1.29 (Table 1). High survivin mRNA expression was seen in 8 of the 22 patients with peritoneal metastasis $(36.4 \%)$ and in 46 of the 85 patients without peritoneal metastasis $(54.1 \%)$; again, not a significant difference.

\section{Discussion}

The aim of our present study was to investigate quantitative values for the expression of survivin mRNA, indicative of a gene encoding a novel inhibitor of apoptosis, in gastric cancer. Expression of survivin mRNA was detected by the real-time PCR method in $98.1 \%$ of cancerous gastric tissues and in $94.4 \%$ of noncancerous gastric tissues. The level of survivin mRNA expression was significantly higher in gastric cancer tissue than in noncancerous gastric tissue. However, immunohistochemical analyses of gastric tissue have previously demonstrated that survivin expression could be detected in $34.5 \%$ to $82.0 \%$ of cancerous gastric cancer tissues, with no survivin expression found in the neighboring normal tissues [20,21]. Similar studies using immunohistochemical analyses of colorectal, mammary, and skin tissues $[14,19,31]$ have also demonstrated survivin expression in cancerous tissues and none in noncancerous tissues.

A few studies using immunohistochemical analyses have demonstrated survivin expression in noncancerous colon and lymph node tissues [32,33]. Survivin expression has also been demonstrated in noncancerous tissue using the reverse transcription-polymerase chain reaction (RT-PCR) method. By this method, survivin mRNA expression was identified in $85.5 \%$ of cancerous lung samples and in $12 \%$ of paired noncancerous lung samples [24]. Similarly, survivin mRNA expression was detected in $63.5 \%$ of cancerous colon samples and in $29.1 \%$ of noncancerous colon mucosa samples [23]. In our study, the level of survivin mRNA expression in noncancerous tissue was low in comparison with that in cancerous tissue, but the expression was, nonetheless, observed in $94.4 \%$ of the noncancerous tissue samples. This result was very high compared to findings in other reports. Our result was attributed to the increased number of PCR cycles used for the real-time PCR method (50 cycles) in the present study, compared to PCR cycle conditions in other studies using conventional RT-PCR methods (30 to 35 cycles). Using real-time PCR methods, the number of amplification cycles required for the detection of a signal of standard RNA was measured using a known number of existing copies. The result was compared with the results of experimental preparations. Based on this, the quantity of survivin mRNA included in preparations was determined from the number of cycles with confirmed survivin expression. The number of amplifications required for the detection of survivin is more important than the quantity of amplified material created. This study therefore sought to demonstrate the presence of survivin mRNA in noncancerous tissue.

Recently, survivin mRNA has been reported to serve important functions in normal tissues. Survivin is re- 
quired for the proliferation of cells during conversion in the G2/M-phase and mitotic progression [34,35]. In addition, the expression of survivin is reported in normal endometrium, where survivin has been demonstrated in the secretory and proliferative phases [36]. Moreover, survivin expression has been identified in normal colonic mucosa in the bases of colonic crypts, which are regarded as proliferation loci [32]. These results show that survivin participates in proliferative functions, supporting the high incidence of survivin mRNA expression in both cancerous and noncancerous gastric tissues shown in the present study.

As survivin mRNA was present in most of our tissue samples, we needed to determine a value above which expression was considered high (i.e., overexpression). We selected the median value of survivin mRNA expression observed in cancerous gastric tissue. Only 15 samples $(14.0 \%)$ of noncancerous tissue exceeded this cutoff value; this proportion was equal to or less than that determined in other studies using the RT-PCR method. Thus, expression values beneath the cutoff value represent levels at which the expression of survivin is necessary for fundamental cell proliferation in normal tissue.

Of the 107 cancerous gastric tissue samples, 54 showed high survivin mRNA expression and 53 showed low expression. Survivin mRNA expression in these two groups was then compared with the pathological findings. Survivin mRNA expression was independent of both histological type and depth of tumor invasion in patients with gastric cancer. High survivin mRNA expression may therefore occur in the early stages of carcinogenesis of gastric cancer through abnormal control mechanisms, irrespective of the histological type of gastric cancer. This is supported by studies in which survivin expression was observed in precancerous lesions such as Bowen's disease and hypertrophic actinic keratosis preceding cutaneous cancer, and in adenomas, which are the precancerous lesions preceding large-bowel cancer [18,37].

In our study, the proportion of patients with high survivin mRNA expression also displaying lymph node metastasis was significantly higher than the proportion of patients with low survivin mRNA expression and lymph node metastasis. This connection between high survivin expression and lymph node metastasis may be related to an earlier finding that survivin expression is connected with microvessel density [38]. Angiogenesis is essential for cancerous tissue to receive adequate nutrition necessary for its continuous growth. Tumors exhibiting high numbers of microvessels have been shown to possess high metastatic potential $[39,40]$. Vascular endothelial growth factor (VEGF) has been nominated as one of the triggers of angiogenesis. VEGF expression has also demonstrated a strong association with the presence of lymph node metastasis [41,42]. Moreover, VEGF stimulation reportedly causes increased expression of survivin [43]. Conversely, survivin may prevent new blood vessels formed by VEGF from disappearing by apoptosis. Thus, VEGF and survivin appear to function cooperatively to increase and maintain newly formed blood vessels. In patients with high survivin expression, newly formed blood vessels are apparently retained, providing greater blood flow to the cancerous tissue and promoting metastasis. In the present study, the value for survivin mRNA expression in the patients with lymphatic invasion was significantly higher that that in the patients without lymphatic invasion. However, no significant differences were found between survivin mRNA expression and vessel invasion.

The relationship between survivin expression and metastasis may also arise from an essential function of survivin: when survivin inhibits apoptosis, the proportion of cancerous cells in a tissue increases with continued growth. Previous studies have indicated that when abnormal cells that would otherwise be removed by apoptosis continue to grow, their potential for invasion and metastasis increases [44,45]. However, in the present study, no relationship was found between the formation of peritoneal metastasis, a condition related to the invasion ability of the cancer, and survivin expression. Therefore, the increasing likelihood of cancer metastasis from increased angiogenesis seems to describe the relationship between the increased lymph node metastasis and the increased expression of survivin found in the present study.

These results indicate that survivin mRNA expression starts to increase in the early stages of carcinogenesis. Moreover, the level of survivin mRNA expression may indicate the potential for lymph node metastasis.

\section{References}

1. Clarke PGH. Development cell death: morphological diversity and multiple mechanisms. Anat Embryol 1990;181:195-213.

2. Eastwood GL. A review of gastrointestinal epithelial renewal and its development of adenocarcinomas of the gastrointestinal tract. J Clin Gastroenterol 1995;21:1-11.

3. Andrikoula M, Tsatsoulis A. The role of Fas-mediated apoptosis in thyroid disease. Eur J Endocrinol 2001;144:561-8.

4. Nagata S, Golstein P. The Fas death factor. Science 1995;267: 1449-56.

5. Baker SJ, Reddy EP. Modulation of life and death by the TNF receptor superfamily. Oncogene 1998;17:3261-70.

6. Brown JM, Wouters BG. Apoptosis, p53, and tumor cell sensitivity to anticancer agents. Cancer Res 1999;59:1391-9.

7. Zhivotovsky B, Joseph B, Orrenius S. Tumor radiosensitivity and apoptosis. Exp Cell Res 1999;248:10-7.

8. Amundoson SA, Myers TG, Fornace AJ Jr. Roles for p53 in growth arrest and apoptosis: putting on the brakes after genotoxic stress. Oncogene 1998;17:3287-99.

9. Shimizu S, Narita M, Tsujimoto Y. Bcl-2 family proteins regulated the release of apoptogenic cytochrome $\mathrm{c}$ by the mitochondrial channel VDAC. Nature 1999;399:483-7. 
10. Adams JM, Cory S. The Bcl-2 protein family. Science 1998;281: 1322-6.

11. Maehara Y, Tomoda M, Hasuda S, Kabashima A, Tokunaga E, Kakeji Y, et al. Prognostic value of p53 protein expression for patients with gastric cancer - a multivariate analysis. Br J Cancer 1999;79:1255-61.

12. Nakata B, Muguruma K, Hirakawa K, Chung YS, Yamashita Y, Inoue $\mathrm{T}$, et al. Predictive value of $\mathrm{Bcl}-2$ and Bax protein expression for chemotherapeutic effect in gastric cancer. A pilot study. Oncology 1998;55:543-7.

13. Ambrosini G, Adida C, Altieri DC. A novel anti-apoptosis gene, survivin, expressed in cancer and lymphoma. Nat Med 1997;3: 917-21.

14. Lo ML, Staibano S, Pannone G, Mignogna MD, Mariggio A, Salvatore G, et al. Expression of the apoptosis inhibitor survivin in aggressive squamous cell carcinoma. Exp Mol Pathol 2001;70: 249-54.

15. Ito T, Shiraki K, Sugimoto K, Yamanaka T, Fujikawa K, Ito M, et al. Survivin promotes cell proliferation in human hepatocellular carcinoma. Hepatology 2000;31:1080-5.

16. Adida C, Haioun C, Gaulard P, Lepage E, Morel P, Briere J, et al. Prognostic significance of survivin expression in diffuse large Bcell lymphomas. Blood 2000;96:1921-5.

17. Islam A, Kageyama H, Hashizume K, Kaneko Y, Nakagawara. A role of survivin, whose gene is mapped to $17 \mathrm{q} 25$, in human neuroblastoma and identification of a novel dominant-negative isoform, survivin-beta/2B. Med Pediatr Oncol 2000;35:550-3.

18. Takamizawa S, Scott D, Wen J, Grundy P, Bishop W, Kimura K, et al. The survivin: fas ratio in pediatric renal tumors. J Pediatr Surg 2001;36:37-42.

19. Tanaka K, Iwamoto S, Gon G, Nohara T, Iwamoto M, Tanigawa N. Expression of survivin and its relationship to loss of apoptosis in breast carcinomas. Clin Cancer Res 2000;6:127-34.

20. Lu CD, Altieri DC, Tanigawa N. Expression of a novel antiapoptosis gene, survivin, correlated with tumor cell apoptosis and p53 accumulation in gastric carcinomas. Cancer Res 1998;58: 1808-12.

21. Okada E, Murai Y, Matsui K, Isizawa S, Cheng C, Masuda M, et al. Survivin expression in tumor cell nuclei is predictive of a favorable prognosis in gastric cancer patients. Cancer Lett 2001;163:109-16.

22. Kato J, Kuwabara Y, Mitani M, Shinoda N, Sato A, Toyama T, et al. Expression of survivin in esophageal cancer: correlation with the prognosis and response to chemotherapy. Int $\mathrm{J}$ Cancer 2001;95:92-5.

23. Sarela AI, Macadam RC, Farmery SM, Markham AF, Guillou PJ. Expression of the antiapoptosis gene, survivin, predicts death from recurrent colorectal carcinoma. Gut 2000;46:645-50.

24. Monzo M, Rosell R, Felip E, Astudillo J, Sanchez JJ, Maestre J, et al. A novel anti-apoptosis gene: re-expression of survivin messenger RNA as a prognosis marker in non-small-cell lung cancers. J Clin Oncol 1999;17:2100-4

25. Japanese Gastric Cancer Association. Japanese classification of gastric carcinoma. 2nd English Ed. Gastric Cancer 1998;1:10-24.

26. Hisatomi H, Nagao K, Kanamaru T, Endo H, Tomimatsu M, Hikiji K. Levels of telomerase catalytic subunit mRNA as a predictor of potential malignancy. Int J Oncol 1999;14:727-32.

27. Fink L, Seeger W, Ermart L, Hänze J, Stahl U, Grimminger F, et al. Real-time quantitative RT-PCR after laser-assisted cell picking. Nat Med 1998;4:1329-33.

28. Biéche I, Olivi M, Champème MH, Vidaud D, Lidereau R, Vidaud M. Novel approach to quantitative polymerase chain re- action using real-time detection: application to the detection of gene amplification in breast cancer. Int J Cancer 1998;78:661-6.

29. Heid AC, Steves J, Livak KJ, Williams PM. Real time quantitative PCR. Genome Res 1996;6:986-94.

30. Chomczynski P, Sacchi N. Single-step method of RNA isolation by acid guanidinium thiocyanate-phenol-chloroform extraction. Anal Biochem 1987;162:156-9.

31. Kawasaki H, Altieri DC, Lu CD, Toyoda M, Tenjo T, Tanigawa $\mathrm{N}$. Inhibition of apoptosis by survivin predicts shorter survival rates in colorectal cancer. Cancer Res 1998;58:5071-4.

32. Gianani R, Jarboe E, Orlicky D, Frost M, Bobak J, Lehner R, et al. Expression of survivin in normal, hyperplastic, and neoplastic colonic mucosa. Hum Pathol 2001;32:119-25.

33. Granziero L, Ghia P, Circosta P, Gottardi D, Strola G, Geuna M, et al. Survivin is expressed on CD40 stimulation and interfaces proliferation and apoptosis in B-cell chronic lymphocytic leukemia. Blood 2001;97:2777-83.

34. Li F, Ambrosini G, Chu EY, Plescia J, Tognin S, Marchisio PC, et al. Control of apoptosis and mitotic spindle checkpoint by survivin. Nature 1998;396:580-4.

35. Li F, Ackermann EJ, Bennett CF, Rothermel AL, Plescia J, Tognin S, et al. Pleiotropic cell-division defects and apoptosis induced by interference with survivin function. Nat Cell Biol 1999;1:461-6.

36. Konno R, Yamakawa H, Utsunomiya H, Ito K, Sato S, Yajima A. Expression of survivin and $\mathrm{Bcl}-2$ in the normal human endometrium. Mol Hum Reprod 2000;6:529-34.

37. Grossman D, McNiff JM, Li F, Altieri DC. Expression of the apoptosis inhibitor, survivin, in nonmelanoma skin cancer and gene targeting in a keratinocyte cell line. Lab Invest 1999;79: 1121-6.

38. Kawasaki H, Toyoda M, Shinohara H, Okuda J, Watanabe I, Yamamoto T, et al. Expression of survivin correlates with apoptosis, proliferation, and angiogenesis during human colorectal tumorigenesis. Cancer 2001;91:2026-32.

39. Xiangming C, Hokita S, Natsugoe S, Tanabe G, Baba M, Takao S, et al. Angiogenesis as an unfavorable factor related to lymph node metastasis in early gastric cancer. Ann Surg Oncol 1998;5: $585-9$.

40. Maeda K, Chung YS, Ogawa Y, Takatsuka S, Kang SM, Ogawa $\mathrm{M}$, et al. Prognostic value of vascular endothelial growth factor expression in gastric carcinoma. Cancer 1996;77:858-63.

41. Funai H, Nishimura G, Harada S, Ninomiya I, Terada I, Fushida $\mathrm{S}$, et al. Expression of vascular endothelial growth factor D is associated with lymph node metastasis in human colorectal carcinoma. Oncology 2003;64:416-22.

42. Kawakami M, Furuhata T, Kimura Y, Yamaguchi K, Hata F, Sasaki K, et al. Quantification of vascular endothelial growth factor-C and its receptor-3 messenger RNA with real-time quantitative polymerase chain reaction as a predictor of lymph node metastasis in human colorectal cancer. Surgery 2003;133:300-8.

43. Tran J, Rak J, Sheehan C, Saibil SD, LaCasse E, Korneluk RG, et al. Marked induction of the IAP family antiapoptotic proteins survivin and XIAP by VEGF in vascular endothelial cells. Biochem Biophys Res Commun 1999;264:781-8.

44. Wyllie AH, Bellamy COC, Bubb AR, Clarke AR, Corbet S, Curtis L, et al. Apoptosis and carcinogenesis. Br J Cancer 1999;80:34-7.

45. Sierra A, Castellsague X, Escobedo A, Lloveras B, G-Ramnrez M, Moreno A, et al. Bcl-2 with loss of apoptosis allows accumulation of genetic alterations: a pathway to metastatic progression in human breast cancer. Int J Cancer 2000;89:142-7. 